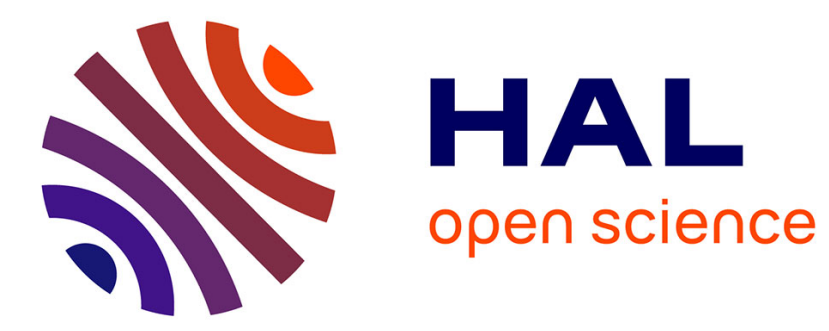

\title{
ICTV Virus Taxonomy Profile: Belpaoviridae 2021
}

Beatriz Soriano, Mart Krupovic, Carlos Llorens, Ictv Report Consortium

\section{To cite this version:}

Beatriz Soriano, Mart Krupovic, Carlos Llorens, Ictv Report Consortium. ICTV Virus Taxonomy Profile: Belpaoviridae 2021. Journal of General Virology, 2021, 102 (11), pp.001688. 10.1099/jgv.0.001688 . pasteur-03462374

\section{HAL Id: pasteur-03462374 \\ https://hal-pasteur.archives-ouvertes.fr/pasteur-03462374}

Submitted on 1 Dec 2021

HAL is a multi-disciplinary open access archive for the deposit and dissemination of scientific research documents, whether they are published or not. The documents may come from teaching and research institutions in France or abroad, or from public or private research centers.
L'archive ouverte pluridisciplinaire HAL, est destinée au dépôt et à la diffusion de documents scientifiques de niveau recherche, publiés ou non, émanant des établissements d'enseignement et de recherche français ou étrangers, des laboratoires publics ou privés.

\section{(ㄷ)(1)}

Distributed under a Creative Commons Attribution| 4.0 International License 


\title{
ICTV Virus Taxonomy Profile: Belpaoviridae 2021
}

\author{
Beatriz Soriano', Mart Krupovic ${ }^{2, *}$, Carlos Llorens ${ }^{1, *}$ and ICTV Report Consortium
}

\begin{abstract}
The family Belpaoviridae comprises metazoan-infecting reverse-transcribing viruses with long terminal repeats, commonly known as Bel/Pao LTR retrotransposons. These viruses share evolutionary history and genes involved in genome replication and virion formation with reverse-transcribing viruses of the families Metaviridae, Pseudoviridae, Retroviridae and Caulimoviridae. These five families form the order Ortervirales. This is a summary of the ICTV Report on the family Belpaoviridae, which is available at ictv.global/report/ belpaoviridae.
\end{abstract}

Table 1. Characteristics of members of the family Belpaoviridae

\begin{tabular}{|ll|}
\hline Example: & Ascaris lumbricoides Tas virus (Z29712), species Ascaris lumbricoides Tas virus, genus Semotivirus \\
\hline Virion & Unknown \\
Genome & Linear single-stranded RNA of $4-10 \mathrm{~kb}$ \\
Replication & Replication by reverse-transcription primed by a host-encoded tRNA \\
Translation & Genomic RNA is translated into one or more polyproteins \\
Host range & Vertebrates, insects and nematodes \\
Taxonomy & $\begin{array}{l}\text { Realm Riboviria, kingdom Pararnavirae, phylum Artverviricota, class Revtraviricetes, order Ortervirales; the genus Semotivirus includes }>10 \\
\text { species }\end{array}$ \\
\hline
\end{tabular}

\section{VIRION}

Little is known about the virion morphology of belpaovirids. However, given that belpaovirids encode a Gag polyprotein with nucleocapsid and capsid protein domains homologous to those of other members of the order Ortervirales [1,2], their replication probably involves the formation of virus-like particles (VLPs), as in the case of retrovirids, metavirids and pseudovirids. Some belpaovirids carry an env-like gene [3], the function of which remains unknown.

\section{GENOME}

Members of the family Belpaoviridae have a genomic organization typical of long terminal repeat (LTR) retrotransposons of the family Metaviridae [4], with one to three genes (gag, pol and env) being flanked by LTRs of $0.2-1.2 \mathrm{~kb}$ [5], and the whole genome being $4.2-10 \mathrm{~kb}$. Downstream of the $5^{\prime}$-LTR is a non-coding region that corresponds to the first portion of the reverse-transcribed genome, followed by an $18 \mathrm{nt}$ primer-binding site that is complementary to a specific region within the $3^{\prime}$-end of a host tRNA ${ }^{\text {Arg }}$ or a tRNA ${ }^{\text {Gly }}$. Upstream of the $3^{\prime}$-LTR is a polypurine tract of about 10 $\mathrm{nt}$, which is responsible for priming the synthesis of the proviral DNA strand. The Gag and Pol polyproteins, encoding respectively the capsid and nucleocapsid domains, and the protease, reverse transcriptase (RT), ribonuclease $\mathrm{H}$ and integrase domains, can be encoded by either one continuous or two overlapping gag and pol genes (Table 1, Fig. 1) [6].

\section{REPLICATION}

Replication is poorly understood, but, given the similarity in both sequences and functional features, it is assumed to be similar

Received 20 September 2021; Accepted 21 September 2021; Published 11 November 2021

Author affiliations: 'Biotechvana, Scientific Park University of Valencia, 46980, Paterna, Valencia, Spain; ${ }^{2}$ Archaeal Virology Unit, Institut Pasteur, Université de Paris, F-75015 Paris, France.

*Correspondence: Carlos Llorens, carlos.llorens@biotechvana.com; Mart Krupovic, mart.krupovic@pasteur.fr

Keywords: ICTV Profile; taxonomy; Belpaoviridae; Semotivirus.

Abbreviations: RT, reverse transcriptase; VLP, virus-like particles.

001688 @ 2021 

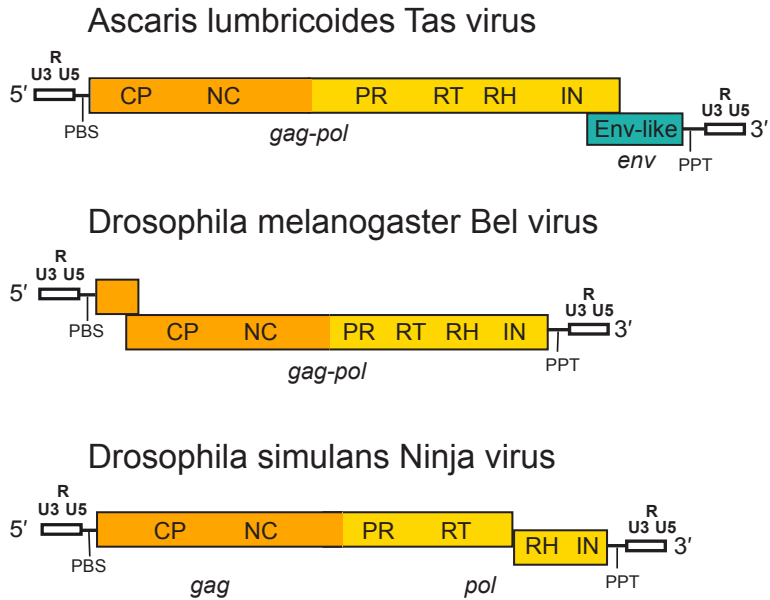

Takifugu rubripes Suzu virus

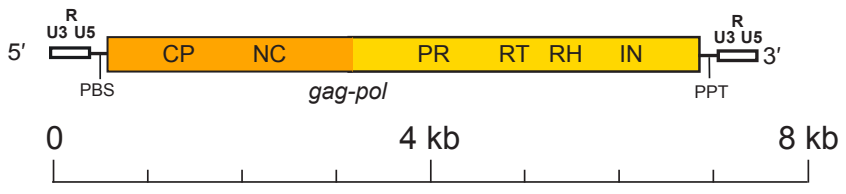

Fig. 1. Full-length genome architectures of representative semotiviruses. Long terminal repeats, including the U3, R and U5 regions are coloured white, and the distinct gag, pol and env regions, are coloured orange, yellow and green, respectively. PBS, primerbinding site; PPT, polypurine tract; CP, capsid protein domain; NC, nucleocapsid protein domain; PR, protease; RT, reverse transcriptase; $\mathrm{RH}$, ribonuclease $\mathrm{H} ; \mathrm{INT}$, integrase; and Env-like, envelope-like protein.

to that of members of the family Metaviridae [4], in which RT mediates the conversion of a full transcript into a dsDNA that is integrated into the host genome by the integrase protein. The host RNA polymerase II then transcribes the integrated provirus to form new virus RNAs, which are capped and polyadenylated by the corresponding host enzymes. These new viral RNAs are exported to the cytoplasm of the host cell, where Gag and Pol are translated to form immature VLPs. The polyproteins are subsequently processed proteolytically by the viral protease, resulting in VLP maturation. RT then reverse-transcribes the new viral RNAs to dsDNA molecules, which are transported back to the nucleus, where they are inserted into new sites of the host cell genome [7].

\section{TAXONOMY}

Current taxonomy: www.ictv.global/taxonomy. Semotivirus, the only genus in the family, was previously placed in the family Metaviridae, but was removed due to its paraphyletic relationship with other genera of the family Metaviridae. Based on the currently known diversity of belpaovirids, additional species and genera are likely to be introduced into the family Belpaoviridae in the future. Within the order Ortervirales, members of the families Belpaoviridae, Metaviridae and Retroviridae have the same Pol domain order, whereas the integrase is either absent (Caulimoviridae) or located upstream of the protease domain (Pseudoviridae) [8].

\section{RESOURCES}

Full ICTV Report on the family Belpaoviridae: ictv.global/ report/belpaoviridae.

GyDB: http://gydb.org

Repbase: https://www.girinst.org/repbase

RepetDB: http://urgi.versailles.inra.fr/repetdb

RexDB: http://repeatexplorer.org

Funding information

Production of this Profile, the ICTV Report, and associated resources was funded by a grant from the Wellcome Trust (WT108418AIA). B.S. was supported by a pre-doctoral research fellowship from Industrial Doctorates of MINECO (grant 659 DI-17-09134).

\section{Acknowledgements}

Members of the ICTV Report Consortium are Stuart G. Siddell, Elliot J. Lefkowitz, Sead Sabanadzovic, Peter Simmonds, F. Murilo Zerbini, Donald B. Smith and Arvind Varsani.

Conflicts of interest

The authors declare that there are no conflicts of interest

References

1. Krupovic M, Koonin EV. Homologous capsid proteins testify to the common ancestry of retroviruses, caulimoviruses, pseudoviruses, and metaviruses. J Virol 2017;91:e00210-17.

2. Krupovic M, Blomberg J, Coffin JM, Dasgupta I, Fan H, et al. Ortervirales: new virus order unifying five families of reverse-transcribing viruses. J Virol 2018;92:e00515-18.

3. de la Chaux N, Wagner A. BEL/Pao retrotransposons in metazoan genomes. BMC Evol Biol 2011;11:154.

4. Llorens C, Soriano B, Krupovic M, ICTV Report Consortium. ICTV Virus Taxonomy Profile: Metaviridae. J Gen Virol 2020;101:1131-1132.

5. Llorens C, Futami R, Covelli L, Domínguez-Escribá L, Viu JM, et al. The Gypsy Database (GyDB) of mobile genetic elements: release 2.0. Nucleic Acids Res 2011;39:D70-4.

6. Marsano RM, Caizzi R. A genome-wide screening of BEL-Pao like retrotransposons in Anopheles gambiae by the LTR_STRUC program. Gene 2005;357:115-121.

7. Fungal BJD. Plant and animal retrotransposon elements. Rawlings ND and Salvesen G (eds). In: Handbook of Proteolytic Enzymes 1. Academic Press; 2013. pp. 248-253.

8. Llorens C, Soriano B, Krupovic M, ICTV Report Consortium. ICTV Virus Taxonomy Profile: Pseudoviridae. J Gen Virol 2021;102:jgv.0.001563. 